PUPIL: International Journal of Teaching, Education and Learning

ISSN 2457-0648

Rasmitadila et al., 2022

Volume 5 Issue 3, pp. 112-128

Received: 19th September 2021

Revised: 20 th December 2021, 3 ${ }^{\text {rd }}$ January 2022, $9^{\text {th }}$ January 2022

Accepted: 10th January 2022

Date of Publication: 20 th January 2022

DOI- https://doi.org/10.20319/pijtel.2022.53.112128

This paper can be cited as: Rasmitadila, Widyasari, Prasetyo, T. E Putri, A. A. (2022). Challenges in The Implementation of Instructional Strategy Model Based on The Brain Natural Learning Systems for inclusive Classroom. PUPIL: International Journal of Teaching, Education and Learning, 5 (3), 112-128.

This work is licensed under the Creative Commons Attribution-NonCommercial 4.0 International License. To view a copy of this license, visit http://creativecommons.org/licenses/by-nc/4.0/ or send a letter to Creative Commons, PO Box 1866, Mountain View, CA 94042, USA.

\title{
CHALLENGES IN THE IMPLEMENTATION OF INSTRUCTIONAL STRATEGY MODEL BASED ON THE BRAIN NATURAL LEARNING SYSTEMS FOR INCLUSIVE CLASSROOM
}

\author{
Rasmitadila \\ Department of Elementary School Teacher Education, Universitas Djuanda, Bogor, Indonesia \\ Rasmitadila@unida.ac.id \\ Widyasari \\ Department of Elementary School Teacher Education, Universitas Djuanda, Bogor, Indonesia \\ Widyasari@unida.ac.id \\ Teguh Prasetyo \\ Department of Elementary School Teacher Education, Universitas Djuanda, Bogor, Indonesia \\ Teguh@unida.ac.id \\ Ayu Anggraini Putri \\ Department of International Relations, Universitas Nasional, Jakarta, Indonesia \\ Ayuanggraini2000@gmail.com
}

\begin{abstract}
One of the problems teachers often face in inclusive classrooms is the difficulty of designing effective and flexible instruction that can meet the needs of all students. This study explores general teacher $(G T)$ opinions on the challenges in implementing instructional strategies based on the
\end{abstract}


natural brain learning systems for inclusive classrooms in elementary schools. Data were collected through classroom observations and semi-structured interviews with seven GTs who have implemented instructional strategies based on the natural brain learning system in an inclusive classroom. Data were analyzed using thematic analysis. The research has four main themes: modification of teaching materials, modification of instructional methods, modification of instructional media, and time. The challenge in implementing instructional strategies based on the natural learning system of the brain lies in the readiness of GTs in facing all changes in the instructional process that GTs has implemented. This challenge will expect to be the experience of GTs in designing more effective learning that must fully support all parties to provide meaningful learning for all students.

\section{Keywords}

Instructional Strategy, Inclusive Classroom, Learning System, Instructional Method, Instructional Media

\section{Introduction}

Instruction in an inclusive classroom is a process that requires the design of activities that must be able to meet learning objectives. All instructional activities must be carried out according to all students' characteristics, learning styles, and abilities, including special needs students (SNSs) (Taole, 2020). Teachers must design instruction that can foster interest in learning, knowledge, social skills, and the advantages of all students, which will develop in their future. For this reason, teachers must be able to design and develop effective instructional strategies for all students. Instructional strategies in inclusive classrooms must consider varied and innovative instructional methods that all students in every learning activity can implement (McGhieRichmond et al., 2007; Rossi, 2018). Teachers must choose instructional methods that can improve all students' academic and non-academic aspects. In the academic aspect, the selected instructional method must provide students with learning experiences (Kou et al., 2020), discuss with each other, practice problem-solving, take joint decisions, and ultimately all instructional activities as meaningful learning. Meanwhile, in the non-academic aspect, teachers must be able to train students to have the ability to collaborate, work together in a team that has different characteristics and abilities, interact and communicate (Trief et al., 2010), which are essential points in the success in the lives of all students, including SNSs. Through the instructional method, students are 
expected to have their strengths to use for development future and weaknesses that must strengthen (Billings, 2014).

In addition to instructional methods, the design of instructional strategies in inclusive classrooms must support the availability of instructional media that are easily accessible to all students. The use of instructional media must prepare the teacher, both in terms of types and costs that support instructional media. The instructional media aims to make students better understand the message of the subject matter delivered by general teachers (GTs) (Krutka \& Damico, 2020). The teacher must know the type of instructional media to be used following the learning styles of all students, for example, audio, visual or audiovisual. Some SNSs with specific categories may have limitations in audio or visual types of instructional media, such as the blind or deaf. The teacher must prepare other kinds of instructional media to convey the material properly. At each stage of the activity, variations in instructional media are the teacher's task so that all students get relevant information and make it easier to achieve instructional activities (Puspitarini \& Hanif, 2019).

Meanwhile, other instructional strategies such as teaching materials are also essential for the teacher to prepare properly. Every student has the right to have teaching materials that are easy to access to understand the subject matter easily. The difference in the characteristics of each student must be anticipated by the teacher well (Kori et al., 2018). Each subject matter must be prepared by GT, especially for SNSs with specific categories, because not every student can use the subject matter easily and is the same as general students (GSs). In addition to teaching materials, other components such as stages and instructional times must also be designed and anticipated by GT effectively so that instructional time is not wasted (Wilson \& Harris, 2004). Instruction can take place according to the time that has been provided. The effectiveness of instructional time in an inclusive classroom is primarily determined by using methods, media, and instructional stages (Schilling, 2017; Daniela \& Lytras, 2018). For this reason, teachers must be able to allocate time according to the needs of each activity and the types of activities that students must go through. Indicators of the success of instruction in an inclusive classroom are primarily determined by the effectiveness of the instructional strategies designed by the teacher (An \& Mindrila, 2020). 


\subsection{Instructional Strategy}

The instructional strategy consists of various parts in choosing a release or launch system, sequencing and integrating learning materials, explaining the learning components that will be included in learning, determining the rules for dividing students in learning, creating a learning framework, and choosing learning media (Dick et al., 2005). According to Suparman (2012), a learning strategy is an approach to regulating the content and learning process as a whole to achieve a learning goal. The components of the learning strategy consist of: a) Learning objectives, consisting of competencies that are expected to be achieved by students at the end of the lesson; b) Content or subject matter with appropriate steps; c) Approach in managing learning related to the use of methods, media \& tools, as well as the allocation of learning time needed. The same definition is also stated by Onweh \& Akpan (2014) that a learning strategy is an approach used by teachers to achieve learning, including using instructional methods such as demonstrations, discussions, and lectures. Learning strategies provide guidelines for inclusive teachers to design learning to be more active and effective Hartman et al. (2018) by involving all learning styles, behaviours, and characteristics of all students. Through inclusive learning strategies, it is expected to build a comfortable and conducive learning climate (Maxwell \& Gurin, 2017) so that learning objectives can be achieved according to the abilities and needs of all students.

\subsection{The Brain's Natural Learning System}

One of the instructional strategies that GTs in an inclusive classroom has successfully implemented is an instructional strategy based on the brain's natural learning system (Given, 2002). The brain's natural learning system consists of five learning systems. First, the emotional learning system, which places teachers as mentors, aims to get students interested in learning and positive behaviour towards the lessons to be learned. Second, the social learning system places students as part of a group to improve their ability to interact and collaborate with other people in a learning community. Students can also work together in making decisions and solving problems. Third, a cognitive learning system that places teachers as facilitators and trains students as problem-solvers and decision-makers. The teacher provides learning activities to explore student knowledge and solve problems from the teacher's subject matter material as a group decision. Fourth, the physical learning system involving all class members in physical, psychomotor, and tactile activities on a topic being studied. Fifth, the reflective learning system lets the teacher understand students' learning styles, strengths, and weaknesses after going through the learning process, which can be 
used as a basis for student development in the future. These five learning systems are designed in one learning strategy divided into three learning activities: initial of instructional activities, main of instructional activities, and closing of instructional activities for inclusive classrooms. We can see the illustration of the three learning activities in Figure 1:

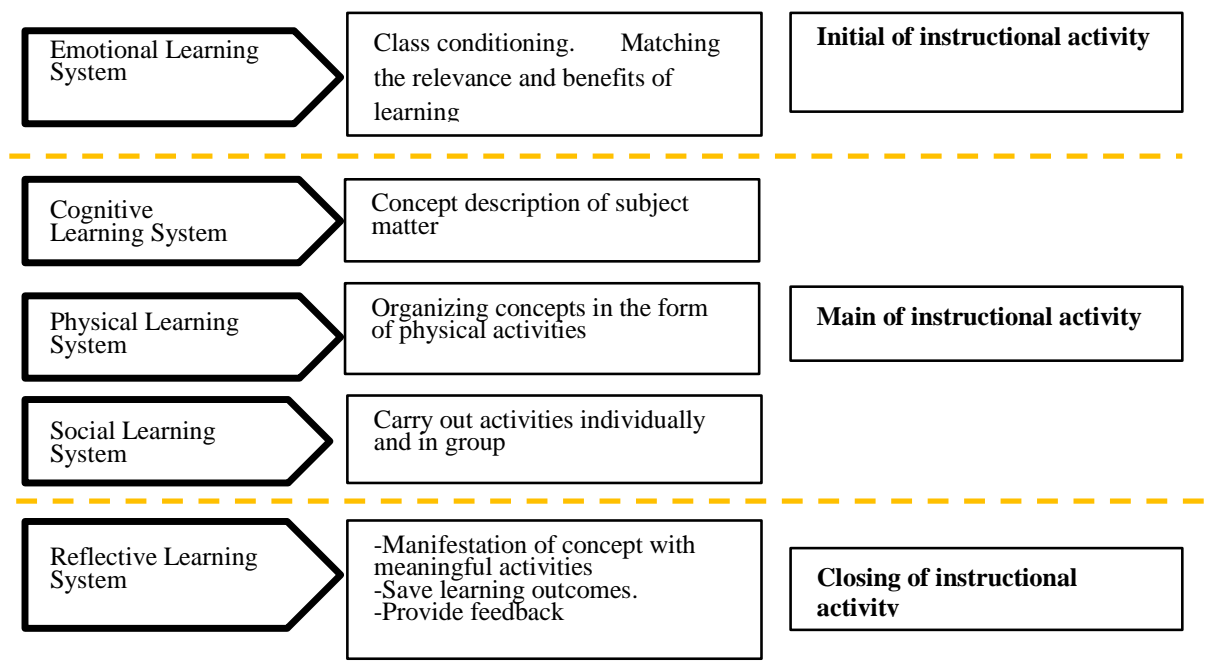

Figure 1: Design of the instructional strategies based on the brain's natural learning systems

(Source:(Given, 2002) developed by Rasmitadila et al., (2021))

\subsection{Inclusive Classroom}

Schools that have implemented inclusive education must prepare inclusive classrooms that are used as places for learning to meet all student needs (Adams et al., 2018). According to D’Amico \& Gallaway (2010), an inclusive classroom is flexibly arranged, accessible to every student with various academic levels, learning styles, behaviours, strengths, weaknesses, or certain disabilities. In addition, an inclusive class is a class that teaches about give and take, creating a class that supports and respects each other in diversity (Sapon-Shevin, 2007). The division of inclusive classes as described by (Sari Rudiyati, n.d.) is as follows: (1) Full inclusion regular classes, children with special needs study together with other children in regular/inclusive classes throughout the day using the same curriculum as those used by children in general; (2) Regular classes with clusters, children with special needs study together with other children in special groups (3) Regular classes with pull-outs, children with special needs study together with other children, but at any time they can be pulled out of class to study with special teachers (4) Regular 
classes with clusters and pull-outs, children with special needs study together with other children in special groups and can be withdrawn from class at any time (5) Special classes with integration, children with special needs study with special teachers, but from time to time they can study with other students in an inclusive class (6) Full special class, children with special needs get special services from a supervising teacher in an inclusive class.

This study aimed to explore GT's opinions on challenges in implementing instructional strategies based on the brain's natural learning systems for inclusive classrooms in elementary schools.

\section{Research Methods}

This research method is a case study that aims to allow researchers to explore and examine data in a specific context or phenomenon. Some selected cases, especially in education, can be people, students, principals, teachers, and even school staff members (Crowe et al., 2011). Case study data are used to describe a case in-depth in real-life comprehensively (Yin, 2012). This study studied the mooring faced by general teachers (GT) in implementing a learning strategy model based on the brain's natural learning system in inclusive classrooms in elementary schools.

\subsection{Participants}

Participants in this study were five GTs in elementary schools who teach in inclusive elementary schools in five inclusive elementary schools in Jakarta and West Java, Indonesia. Descriptive data about the characteristics demographic (gender, teaching experience, educational level) of the GTs included in the GTs in the study are presented in Table 1:

Table 1: Participant information

\begin{tabular}{|l|l|c|l|}
\hline Name of GT (Initial) & Gender & Teaching Experience (Year) & Level of Education \\
\hline SA & Female & 7 & Bachelor \\
\hline DN & Female & 10 & Bachelor \\
\hline SS & Female & 5 & Bachelor \\
\hline JNI & Female & 20 & Bachelor \\
\hline SBS & Female & 7 & Bachelor \\
\hline
\end{tabular}

(Source: Rasmitadila.et.al, (2021))

Based on Table 1, it can explain that all participants have had a good teaching experience because they have a good level of education too. Meanwhile, students with special needs (SNSs) in this study consisted of various characteristics such as slow learning students, autism, ADHD, and dyslexia.

\subsection{Data Collection}


Data was collected through class observation and semi-structured interviews with openended questions between the researcher and the GT. Before conducting the research, GT had been given training and practice on instructional strategies based on the brain's natural learning system in inclusive classrooms. The researcher and GTs designed instruction based on the brain's natural learning system, which describes the initial learning activities until the closing of instructional activities. Learning materials are tailored to the subjects to be taught in each class. The lesson is designed for three meetings for 1.5-2 hours. At the time of observation, the researcher recorded all instructional activities, including the implementation of instruction. The results of observations were in field notes and transcribed according to the activities carried out. The observation instrument used was in the form of fields that had to be checked and explained by the researcher, which reflected the five learning systems, which consisted of classroom conditioning; the relevance and benefits of learning; learning objectives; implementation of individual and group activities; organize concepts in the form of physical activities; description of the concept of learning materials; meaningful activities; save learning outcomes; evaluate the concept (test/nontest).

Meanwhile, interviews were conducted using interview guides to GTs. The interview contents were in implementing instructional strategies based on the brain's natural learning system, which previously had an interview guide made. In detail, the interview contents are related to the learning implementation time, the instructional sequence/steps, methods and media, and the teaching materials used in learning. Interviews were conducted for about two hours, over two days (See Appendix 1).

\subsection{Data Analysis}

Data were analyzed using the inductive thematic analysis technique to explore each participant's perceptions to produce an appropriate theme (Galloway \& Jenkins, 2009). The data generated from each participant in the form of responses were made in several stages. In the first stage, codes (keywords) representing participant statements are made not to overlap. The second stage is the categorization of the codes that have been made. With the researcher's large amount of data, coding and categorization easier used the Nvivo 12 application. Finally, all interview data were entered and given codes and categories. Researchers analyze each categorization to allow for the integration or unification of codes to be more effective. This inductive technique enables the identification of themes expressed by participants in response to research questions (Liu, 2011). 


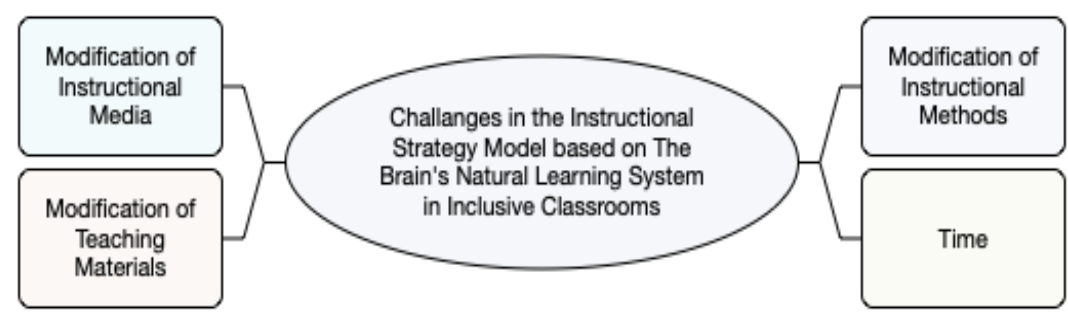

Figure 1: The results of data analysis challenges in the implementation of instructional strategy model based on the brain's natural learning system in inclusive classrooms

(Source: Rasmitadila, et.al (2021))

\section{Results and Discussion}

Based on the data analysis performed, the research has four main themes: modification of teaching materials, modification of instructional methods, modification of instructional media, and time. The explanation of each of the themes is below:

\subsection{Modification of Teaching Materials}

Teaching materials consist of topics or sub-topics to be given to all students regularly and in inclusive classrooms. Every student, including SNSs, must use teaching materials. To be used by all students, the teaching materials must be designed and arranged according to student characteristics. Teachers must develop effective teaching materials so that the transfer of knowledge to all students can easily occur (Chew \& Cerbin, 2021; Akinbobola, 2015). For SNSs, one means of understanding subject matter through teaching materials designed by teachers following the limitations and strengths of SNSs. For example, for students with visual impairments, the teaching materials must be able to use Braille letters on paper that has been adapted for the visually impaired.

For teachers, in implementing instructional strategies based on the brain's natural learning system in an inclusive classroom, the teacher must modify teaching materials with different variations due to other groups of students. The physical appearance of teaching materials such as the types of blind, disabled, or with limitations physical require skills special so that the teaching materials follow the characteristics of the SNSs. Teachers still have limitations in making special teaching materials that also need special skills (Gerber, 2005). In every lesson that requires special attention for SNSs, teachers still use the same teaching materials as GS. This opinion is as expressed by one of the GT: 
"I still find it difficult to design teaching materials for blind students, for example, because it requires skills special such as Braille or others that require modification."

Some of the challenges teachers face in designing teaching materials, in general, are also included in the inclusive classroom (Dewsbury \& Brame, 2019). Among others, teachers need a long time creating teaching materials so that all students can use them, especially SNSs; teachers still do not understand the characteristics of students, so the teaching materials used are not following the characteristics of SNSs. The impact is that learning relies on oral information conveyed by the teacher, and it can cause SNSs not to understand the lessons conveyed by the teacher (Taylor, 2020).

\subsection{Modification of Instructional Method}

The instructional method is a technique used by teachers in delivering subject matter to understand it (Zendler et al., 2018). In an inclusive classroom, instructional methods are an important component that teachers must select and use to convey the subject matter correctly to all students, including SNSs (Rush-Idigo, 2017). Teachers must use appropriate instructional methods, and all students can be involved in instruction. In implementing the instructional strategy based on the brain's natural learning system, choosing an instructional method that can embrace all students and active student involvement still requires teachers' ability in depth. Each learning system is still designed separately, although, in practice, each learning system can be integrated with other learning systems so that the instructional methods used can be more effective. But in practice, the teacher still uses different instructional methods in the five learning systems, so teachers need a long time to complete a learning system. This is as conveyed by one of the GT:

"I have to think of a variety of instructional methods to complete all learning systems to the maximum so that the instructional time becomes longer."

The selection of instructional methods, especially in inclusive classrooms, aims to convey the material well to all students according to student characteristics (Goldwasser \& Hubbard, 2019). The impact is that the teacher understands the students' abilities in understanding the material. In addition, the teacher can also understand the abilities and potentials of students, including SNSs. For this reason, before the teacher starts learning, instructional methods have been made based on students' characteristics, learning styles, abilities, weaknesses, and strengths. It is hoped that with the suitable instructional method, all students in an inclusive classroom will bring 
out their best abilities, both in academic and non-academic scope (Wingate, 2015; Rasmitadila et al., 2020).

\subsection{Modification of Instructional Media}

The use of instructional media in an inclusive classroom is to clarify the meaning of the materials (An, 2020). The teacher will convey to all students with different characteristics to achieve instructional objectives. Although each SNSs has other characteristics and weaknesses, instructional media is expected to help students understand the subject matter. Each student is expected to be motivated to learn can achieve instructional objectives. In the implementation of instruction based on the brain's natural learning system, several things that become challenges for GT include: requiring supporting facilities and infrastructure, both audio, visual, and audiovisual that are not available in schools; funds to make instructional media that the school does not provide, so that the teachers have to spend their funds; teacher competence that must be continuously updated at any time, adjusting to the speed of technology that is currently developing. The tendency of all students, including SNSs, to current technology, causes teachers to adapt to these changes in development.

Teachers must continue to design instructional media relevant and easy to use by all students, including SNSs. As with the use of instructional methods, the teacher must also use instructional media in various ways according to the learning system. Teacher innovation in making instructional media in each learning system must be developed, even though not every teacher has the skills to make instructional media. Simple instructional media (materials that can obtain from around students), maybe the teacher can use in instruction based on the brain's natural learning system. But when it comes to technology, it requires a large amount of cost. So that the media used is ultimately the same on each instructional topic. This opinion follows one of the GT:

"I was a bit difficult when making instructional media in every learning system, so I need the time and cost more than instructional media used more easily used by the students."

Instructional media is inclusive classrooms that aim to foster the interest and motivation of all students when studying (Starcic, 2010; Rasmitadila et al., 2019). Especially for SNSs, the use of instructional media following their characteristics and learning styles makes it easier for SNSs to understand the teacher's messages of the subject matter. However, like the instructional method, instructional media in an inclusive classroom does require variation and innovation from the teacher to understand the material that the teacher is giving (Orlich et al., 2012). 


\subsection{Time}

The use of instructional time is one component of the instructional strategy that the teacher must consider. One of the main indicators for teachers that the instructional strategies can achieve used effectively in addition to instructional objectives can be adequately achieved is the effective use of time (Arends \& Kilcher, 2010). The teacher must divide time on each topic that students will study to have no shortages or strengths. It is hoped that the use of time must also align with the understanding obtained by students of the subject matter given. Ideally, the instructional time provided by the teacher should be able to meet the instructional objectives and knowledge of each student (Kennedy et al., 2011). The challenge faced by GT in implementing strategies based on the brain's natural learning system is the lack of instructional time provided with the implementation of the designed learning system.

The teacher still has to adjust all the components of the instructional strategy, such as instructional methods, instructional media, and instructional stages, so that the time that has been designed is longer than the time allotted. The transfer of each learning system requires sufficient

time so that each learning system produces maximum goals. All students take a shift considerably from one topic to another topic. Teachers also need adjustment time to move from one learning system to the next learning system. Another challenge is that the time provided by the teacher on one topic is longer than the time allotted (Neumerski, 2013). This condition caused the understanding of the material and its explanation longer when the teacher delivered it to all students. The varied characteristics and types of SNSs caused the teacher to explain the material one by one to each SNS. This opinion follows GT's opinion:

"For each learning topic, I need a long time so that all students understand the subject matter I teach, especially SNSs."

Instructional time in inclusive classrooms requires great attention by GT. Using the instructional time aims to make the teacher understand the turn of each topic and see whether, with the time provided, all students have understood the lesson (Pham \& Renshaw, 2013; Elliott, 2012). The use of instructional time is very dependent on the methods, media, and learning stages used. However, if all components of the instructional strategy are following the teacher's design, then can implement time appropriately provided.

\section{Conclusions}


Challenges in implementing instructional strategies based on the brain's natural learning systems result from improving the instructional process in an inclusive classroom to make it more effective. The various challenges faced by GT must be overcome by GT in the future so that instruction in inclusive classrooms is more varied and provides more meaningful learning to every student. Each GT still needs more time and experience in implementing instructional strategies based on the brain's natural learning system. All learning components must be designed and implemented according to the characteristics and types of SNSs so that the instructional strategies designed in their implementation can achieve instructional objectives well. Instructional strategies based on the brain's natural learning system are very suitable for inclusive classes at every level of education. All stakeholders (government, schools, parents, community) must encourage inclusive schools to implement this instructional strategy to create social learning for every child.

This study has limitations, especially those related to the number of inclusive elementary schools that implement learning strategies based on the brain's natural learning system. Future research hopes that the number of inclusive elementary schools can increase further, and more socialization can be carried out to inclusive schools so that evaluation and changes to this strategy can be more flexible to get a more optimal model by developing inclusive education.

\section{Acknowledgment}

The authors wish to thank the Ministry of Education, Culture, Research, and Technology of the Republic of Indonesia as a part of the Research Grant PTUPT (2021). Thank the Directorate of Research and Service of Universitas Djuanda, which supported the research.

\section{REFERENCES}

Adams, D., Harris, A., \& Jones, M. S. (2018). Teacher-parent collaboration for an inclusive classroom: Success for every child. MOJES: Malaysian Online Journal of Educational Sciences, 4(3), 58-72.

Akinbobola, A. O. (2015). Enhancing Transfer of Knowledge in Physics through Effective Teaching Strategies. Journal of Education and Practice, 6(16), 37-44. 
An, Y. (2020). Designing Effective Gamified Learning Experiences. International Journal of Technology in Education, 3(2), 62-69.https://doi.org/10.46328/ijte.v3i2.27

An, Y., \& Mindrila, D. (2020). Strategies and Tools Used for Learner-Centered Instruction. International Journal of Technology in Education and Science, 4(2), 133143.https://doi.org/10.46328/ijtes.v4i2.74

Arends, D., \& Kilcher, A. (2010). Teaching for student learning: Becoming an accomplished teacher. Routledge.https://doi.org/10.4324/9780203866771

Billings, T. J. (2014). Middle school configuration relationship with eighth-grade achievement with administrator perceptions of strengths and weaknesses. Azusa Pacific University.ProQuest Dissertations Publishing.

Chew, S. L., \& Cerbin, W. J. (2021). The cognitive challenges of effective teaching. The Journal of Economic Education, 52(1), 17-40.https://doi.org/10.1080/00220485.2020.1845266

Crowe, S., Cresswell, K., Robertson, A., Huby, G., Avery, A., \& Sheikh, A. (2011). The case study approach. BMC Medical Research Methodology, 11(1), 1-9.

D’Amico, K. E., \& Gallaway, K. (2010). Differentiated instruction for the middle school science teacher: Activities and strategies for an inclusive classroom (Vol. 3). John Wiley and Sons.

Daniela, L., \& Lytras, M. (2018). Learning Strategies and Constructionism in Modern Education Settings. IGI Global.https://doi.org/10.4018/978-1-5225-5430-1

Dewsbury, B., \& Brame, C. J. (2019). Inclusive teaching. CBE-Life Sciences Education, 18(2), fe2.https://doi.org/10.1187/cbe.19-01-0021

Dick, W., Carey, L., \& Carey, J. O. (2015). The systematic design of instruction.Pearson/Allyn and Bacon

Elliott, J. (2012). Developing a science of teaching through lesson study. International Journal for Lesson and Learning Studies.https://doi.org/10.1108/20468251211224163

Galloway, F. J., \& Jenkins, J. R. (2009). The adjustment problems faced by international students in the United States: A comparison of international students and administrative perceptions at two private, religiously affiliated universities. NASPA Journal, 46(4), 661673.https://doi.org/10.2202/1949-6605.5038 
Gerber, M. M. (2005). Teachers are still the test: Limitations of response to instruction strategies for identifying children with learning disabilities. Journal of Learning Disabilities, 38(6), 516-524.https://doi.org/10.1177/00222194050380060701

Given, B. K. (2002). Teaching to the brain's natural learning systems. ASCD.

Goldwasser, M. M., \& Hubbard, M. E. (2019). Creating and Maintaining Inclusive Classrooms. NA-NA.Forum on Public Policy Online.

Hartman, P., Renguette, C., \& Seig, M. T. (2018). Problem-based teacher-mentor education: Fostering literacy acquisition in multicultural classrooms. Interdisciplinary Journal of Problem-Based Learning, 12(1), 6.https://doi.org/10.7771/1541-5015.1659

Kennedy, M. J., Hart, J. E., \& Kellems, R. O. (2011). Using enhanced podcasts to augment limited instructional time in teacher preparation. Teacher Education and Special Education, 34(2), 87-105.https://doi.org/10.1177/0888406410376203

Kori, K., Pedaste, M., \& Must, O. (2018). The academic, social, and professional integration profiles of information technology students. ACM Transactions on Computing Education (TOCE), 18(4), 1-19.https://doi.org/10.1145/3183343

Kou, Y., Peng, X., Dingwell, C. E., Reisbick, S. A., Tonks, I. A., \& Sitek, A. A. (2020). Learning Experience Reports Improve Academic Research Safety. Journal of Chemical Education.https://doi.org/10.1021/acs.jchemed.0c00133

Krutka, D. G., \& Damico, N. (2020). Should we ask students to tweet? Perceptions, patterns, and problems of assigned social media participation. Contemporary Issues in Technology and Teacher Education, 20(1), 142-175.

Liu, L. (2011). An international graduate student's ESL learning experience beyond the classroom. TESL Canada Journal, 77-92.https://doi.org/10.18806/tesl.v29i1.1090

Maxwell, K., \& Gurin, P. (2017). Using Dialogue to Create Inclusive Classrooms: A Case Study from a Faculty Institute. Liberal Education, 103, n3-4.

McGhie-Richmond, D., Underwood, K., \& Jordan, A. (2007). Developing Effective Instructional Strategies for Teaching in Inclusive Classrooms. Exceptionality Education Canada, Vol. $17(1), 27-52$.

Neumerski, C. M. (2013). Rethinking instructional leadership, a review: What do we know about principal, teacher, and coach instructional leadership, and where should we go from here? 
Educational Administration Quarterly, 49(2), 310-

347.https://doi.org/10.1177/0013161X12456700

Onweh, V. E., \& Akpan, U. T. (2014). Instructional strategies and students academic performance in electrical installation in technical colleges in Akwa Ibom State: Instructional skills for structuring appropriate learning experiences for students. International Journal of Educational Administration and Policy Studies, 6(5), 8086.https://doi.org/10.5897/IJEAPS2014.0347

Orlich, D. C., Harder, R. J., Callahan, R. C., Trevisan, M. S., \& Brown, A. H. (2012). Teaching strategies: A guide to effective instruction. Cengage Learning.

Pham, T. T. H., \& Renshaw, P. (2013). How to enable Asian teachers to empower students to adopt student-centred learning. Australian Journal of Teacher Education, 38(11), 5.https://doi.org/10.14221/ajte.2013v38n11.4

Puspitarini, Y. D., \& Hanif, M. (2019). Using Learning Media to Increase Learning Motivation in Elementary School. Anatolian Journal of Education, 4(2), 5360.https://doi.org/10.29333/aje.2019.426a

Rasmitadila, R., Achmad, S., \& Teguh, P. (2019). Teacher-Students' Instructional Interactions Analysis (TSIIA): A Case Study in Inclusive English Classrooms in Indonesia. The International Journal of Interdisciplinary Educational Studies, 14(1), 1-

\section{2.https://doi.org/10.18848/2327-011X/CGP/v14i01/1-22}

Rasmitadila, R., Widyasari, W., Teguh, P., Megan Asri, H., Reza, R., Achmad, S., Muhammad, N., \& Rusi Rusmiati, A. (2020). Model of instructional strategy based on the brain's natural learning system in inclusive classrooms: Special teacher perceptions. International Journal of Advanced Science and Technology.29(7), 3200-3211

Rasmitadila, R., Widyasari, W., Teguh, P., Reza, R., Achmad, S., \& Rusi Rusmiati, A. (2021). General Teachers' Experience of The Brain's Natural Learning Systems-Based Instructional Approach in Inclusive Classroom. International Journal of Instruction, 14(3), 95-116.https://doi.org/10.29333/iji.2021.1436a

Rossi III, L. A. (2018). Special Education and STEM Education Teacher Credentials and Instructional Preparedness for Inclusive STEM Education (Doctoral dissertation, Virginia Tech). 
Rush-Idigo, Kimberly. L. (2017). Co-Teaching and Collaboration: The Effects of Planning and Implementing Differentiated-Instruction in an Inclusive Classroom to Improve Student Achievement. ProQuest LLC.

Sapon-Shevin, M. (2007). Widening the circle: The power of inclusive classrooms. Beacon Press.

Sari Rudiyati, M. P. (n.d.). Potret Sekolah Inklusif di Indonesia. Retrieve from http://staffnew.uny.ac.id/upload/130543600/penelitian/Potret+Sekolah+Inklusif+di+Indo nesia.pdf

Schilling, J. (2017). Instructional strategy: Didactic media presentation to optimize student learning. Athletic Training Education Journal, 12(1), 5158.https://doi.org/10.4085/120151

Starcic, A. I. (2010). Educational technology for the inclusive classroom. Turkish Online Journal of Educational Technology-TOJET, 9(3), 26-37.

Suparman, A. (2012). Desain instruksional modern: Panduan para pengajar dan inovator pendidikan. Erlangga

Taole, M. J. (2020). Diversity and inclusion in rural South African multigrade classrooms. International Journal of Inclusive Education, 24(12), 12681284.https://doi.org/10.1080/13603116.2018.1520310

Taylor, K. (2020). One-Stop Lesson Planning: How Universal Design for Learning Can Help Students Who Are Deaf or Hard of Hearing. Odyssey: New Directions in Deaf Education, $21,48-51$.

Trief, E., Bruce, S. M., \& Cascella, P. W. (2010). The selection of tangible symbols by educators of students with visual impairments and additional disabilities. Journal of Visual Impairment \& Blindness, 104(8), 499-504.https://doi.org/10.1177/0145482X1010400806

Wilson, V., \& Harris, M. (2004). Creating change? A review of the impact of design and technology in schools in England. Volume 15 Issue 2 (Spring 2004).https://doi.org/10.21061/jte.v15i2.a.4

Wingate, U. (2015). Academic literacy and student diversity: The case for inclusive practice. Multilingual matters.https://doi.org/10.21832/9781783093496

Yin, R. K. (2012). Case study methods.https://doi.org/10.1037/13620-009 
Zendler, A., Klaudt, D., \& Seitz, C. (2018). Instructional Methods in STEM and English Subjects: A Validation Study. International Journal of Research in Education and Science, 4(2), 686-702.https://doi.org/10.21890/ijres.438378

\section{Appendix 1}

\section{Questioner of Interview}

1. Can the instructional strategy based on the brain's natural learning system improve your classroom learning outcomes?

2. Does the instructional strategy based on the brain's natural learning system suitable to be applied to inclusive classrooms?

3. Do teachers need to make special preparations when implementing the instructional strategy based on the brain's natural learning system model?

4. What are the main obstacles in implementing the instructional strategy based on the brain's natural learning system model

5. What are the supporting factors for implementing the instructional strategy based on the brain's natural learning system model?

6. What are your suggestions or input regarding the instructional strategy based on the brain's natural learning system? 